\title{
GMR
}

\section{Restoration over time and sustainability of Schinus terebinthifolius Raddi}

\author{
S.V. Álvares-Carvalho', R. Silva-Mann², I.B. Gois ${ }^{3}$, M.F.V. Melo ${ }^{4}$, \\ A.S. Oliveira ${ }^{5}$, R.A. Ferreira ${ }^{6}$ and L.J. Gomes ${ }^{6}$ \\ ${ }^{1}$ Programa de Pós-Graduação em Agricultura e Biodiversidade, \\ Laboratório do Grupo de Pesquisa em Conservação, \\ Melhoramento e Gestão de Recursos Genéticos/GENAPLANT, \\ Universidade Federal de Sergipe, São Cristóvão, SE, Brasil \\ ${ }^{2}$ Laboratório do Grupo de Pesquisa em Conservação, \\ Melhoramento e Gestão de Recursos Genéticos/GENAPLANT, \\ Departamento de Engenharia Agronômica, Universidade Federal de Sergipe, \\ São Cristóvão, SE, Brasil \\ ${ }^{3}$ Programa de Pós-Graduação em Genética e Melhoramento, \\ Universidade Federal de Viçosa, Viçosa, MG, Brasil \\ ${ }^{4}$ Centro de Ciências Agrárias, Universidade Federal de Alagoas, \\ Rio Largo, AL, Brasil \\ ${ }^{5}$ Universidade do Estado de Mato Grosso, Cáceres, MT, Brasil \\ ${ }^{6}$ Centro de Ciências Agrárias Aplicadas, Departamento de Ciências Florestais, \\ Universidade Federal de Sergipe, São Cristóvão, SE, Brasil \\ Corresponding author: S.V. Álvares-Carvalho \\ E-mail: sheilaalvares@yahoo.com.br/carvalhosva@gmail.com
}

Genet. Mol. Res. 16 (2): gmr16029669

Received March 14, 2017

Accepted April 24, 2017

Published May 31, 2017

DOI http://dx.doi.org/10.4238/gmr16029669

Copyright (C) 2017 The Authors. This is an open-access article distributed under the terms of the Creative Commons Attribution ShareAlike (CC BY-SA) 4.0 License.

ABSTRACT. The success of recovery programs on degraded areas
is dependent on the genetic material to be used, which should present
heterozygosity and genetic diversity in native and recovered populations.
This study was carried out to evaluate the model efficiency to enable
the recovery of a degraded area of the Lower São Francisco, Sergipe,

Genetics and Molecular Research 16 (2): gmr16029669 
Brazil. The target species for this study was Schinus terebinthifolius Raddi. Three populations were analyzed, the recovered area, seed-tree source population, and native tree population border established to the recovered area. The random amplified polymorphic DNA (RAPD) markers were used for diversity analysis. Genetic structure was estimated to evaluate the level of genetic variability existent in each population. There was no correlation between the spatial distribution and the genetic distances for all trees of the recovered area. The heterozygosity present in the recovered population was higher than the native tree population. The seed-tree source population presents genetic bottlenecks. Three clusters were suggested $(\Delta \mathrm{K}=3)$ with non-genetic structure. High intra-population genetic variability and inter-population differentiation are present. However, gene flow may also introduce potentially adaptive alleles in the populations of the recovered area, and the native population is necessary to ensure the sustainability and maintenance of the populations by allelic exchange.

Key words: Recovery programs; Inbreeding; Gene flow; Pink pepper; Seed collection

\section{INTRODUCTION}

In Brazil, all the major economic cycles, such as wood, sugarcane, gold mining exploration, followed by coffee and industrialization, were based on the logic of higher gain in the short term, resulting in strong changes in natural environments. These events were intense along the coastland, where the first colonization centers were settled, and which was originally occupied by the Atlantic Forest (Lino, 2013). The State of Sergipe has an area of approximately $21,918.4 \mathrm{~km}^{2}$, which is approximately the same area of Israel $\left(20,770 \mathrm{~km}^{2}\right)$, El Salvador $\left(21,041 \mathrm{~km}^{2}\right)$, and Haiti $\left(27,750 \mathrm{~km}^{2}\right)$. The state is the smallest of the Brazilian confederation with some particularities, such as eight river basins, the mouth of the São Francisco River, and the Atlantic Forest and Caatinga Biomes. Sergipe is one of the 17 Brazilian states with Atlantic Forest remnants (Brasil, 2006); these forest areas are small and highly fragmented due to the large human impact (RBMA, 2008).

As a result of the fragmentation process to which ecosystems are exposed, their restoration can be an instrument for the establishment of ecological corridors, and the gene flow continuity, which is necessary for the maintenance of species and populations viability. Therefore, the analysis of population genetic structure is necessary for both the knowledge in the maintenance of the existing populations and for the population that will compose the recovery source of a degraded area. Thus, for the success of recovery programs, the genotypes should present the highest heterozygosity possible, since the succession of the area will depend on the genetic produced locally in further generations (Wang, 2005). And for these activities, seeds must be collected from populations that have reasonable levels of genetic variability and with a minimum of inbreeding (Sebbenn et al., 2003).

With the recovery models of degraded areas, genetic connectivity must be continually achieved among and within populations to manage the species and to evidence if the historical and current connectivity can be distinguished (Frankham et al., 2014). Substantial increase in

Genetics and Molecular Research 16 (2): gmr16029669 
the effective size $\left(N_{\mathrm{E}}\right)$ can usually be carried out in isolated populations of a given species, since it had previously been connected by gene flow, and can become reconnected using artificial gene flow, or habitat corridors (Frankham et al., 2010).

However, to establish artificial corridors, the seeds should be spread or collected for seedling production and planting, which is a procedure that not always samples all the genotypic diversity of seed source populations, mainly due to the low number of individuals in fragmented native areas. As a result, most of the time, the few genotypes represented in seed sampling lots allow the production, in the nursery, of half-sib seedlings from the same individual. Thus, the objectives of the present study were to evaluate the maintenance of the genetic diversity of the Schinus terebinthifolius Raddi in the recovery area and to point out the perspective for further tree populations.

\section{MATERIAL AND METHODS}

Three populations were used for analysis: recovered population (R), seed source population $(\mathrm{P})$, and native population $(\mathrm{N})$ located at the border of the recovered area. The recovered area $(\mathrm{R})$ is located at the Mãe Natureza Farm $\left(10^{\circ} 15^{\prime} 24^{\prime \prime} \mathrm{S} / 36^{\circ} 38^{\prime} 31^{\prime \prime} \mathrm{W}\right)$ in the municipality of Santana do São Francisco-SE $\left(10^{\circ} 18^{\prime} 11 " \mathrm{~S} / 36^{\circ} 35^{\prime} 56^{\prime \prime} \mathrm{W}\right)$. The recovered population was established in June 2003, and is compose of 12 Brazilian native species (Table 1), being 17 individuals from seeds of S. terebinthifolius from two regions: São Cristóvão-SE (P), and the National Forest of Ibura, located in the municipality of SocorroSE $\left(10^{\circ} 50^{\prime} 32^{\prime \prime} \mathrm{S} / 37^{\circ} 8^{\prime} 24^{\prime \prime} \mathrm{W}\right)$. Fourteen individuals were sampled in the seed source natural population (P) located on the campus of the Federal University of Sergipe, in São CristóvãoSE $\left(10^{\circ} 55^{\prime} 35^{\prime \prime} \mathrm{S} / 37^{\circ} 6^{\prime} 9^{\prime \prime} \mathrm{W}\right)$. The native population $(\mathrm{N})$ is located in Santana do São FranciscoSE, approximately $2 \mathrm{~km}$ far from the recovered area, on the banks of São Francisco River. This area is inserted in a region with intense community extractive activity. The same number of individuals was used for all populations, based on the minimum number of specimens found.

For RAPD analysis, DNA extraction was carried out using $2 \mathrm{~g}$ young leaves macerated with liquid nitrogen and $2 \%$ cetyltrimethylammonium bromide (CTAB) $2 \mathrm{X}$ buffer $(100 \mathrm{mM}$ Tris, $\mathrm{pH}$ 8.0, $20 \mathrm{mM}$ EDTA, $\mathrm{pH}$ 8.0, $1.4 \mathrm{M} \mathrm{NaCl}$ and $1 \% \mathrm{PVP}$ ) and $20 \mu \mathrm{L} \beta$-mercaptoethanol, following the protocol described by Nienhuis et al. (1995), with modifications.

In the amplification reactions, $3.0 \mu \mathrm{L}$ DNA, $2.92 \mu \mathrm{L}$ ultrapure $\mathrm{H}_{2} \mathrm{O}, 1 \mu \mathrm{L} \mathrm{MgCl}_{2}, 1.04$ $\mu \mathrm{L}$ dNTPs, $1.04 \mu \mathrm{L}$ BSA, $1.0 \mu \mathrm{L}$ PCR 10X buffer (200 mM Tris-HCl, pH 8.4; $500 \mathrm{mM} \mathrm{KCl})$ $0.2 \mu \mathrm{L}$ Taq Polymerase, and $2.5 \mu \mathrm{L}$ decamer oligonucleotides were used (Williams et al., 1990). Amplifications were carried out in the Biometrics Tpersonal thermocycler, programmed for an initial cycle at $94^{\circ} \mathrm{C}$ for $5 \mathrm{~min}$, followed by 45 cycles at $94^{\circ} \mathrm{C}$ for $60 \mathrm{~s}$, $36^{\circ} \mathrm{C}$ for $2 \mathrm{~min}$, and $72^{\circ} \mathrm{C}$ for $60 \mathrm{~s}$.

Amplification products for 20 oligonucleotides were separated by electrophoresis on $0.8 \%$ agarose gel in TBE $0.5 \mathrm{X}$ buffer (Tris-borate, Tris base, boric acid, EDTA, and water) stained with $25 \mu \mathrm{L} / 500 \mathrm{~mL}$ ethidium bromide of distilled water, and visualized under ultraviolet light.

For the evaluation of the results obtained in RAPD, each fragment present on the gel was assigned with one (1), and each fragment absent on the gel was assigned with 0 (zero). A binary matrix was constructed and used to estimative the genetic similarities using the Jaccard coefficient by the statistical package NTSYS-pc version 2.1. Similarity clusters were obtained and represented in a dendrogram and performed using unweighted pair group method with

Genetics and Molecular Research 16 (2): gmr16029669 
arithmetic mean (Rohlf, 2001). Correlation analysis between spatial and genetic distances (Mantel test) was obtained by the NTSYS-pc version 2.1 software.

Genetic structure of populations and the principal coordinates analysis (PCoA) were obtained using the GenAlEx software (Peakall and Smouse, 2006) that estimated: number of observed alleles $\left(N_{\mathrm{A}}\right)$, number of effective alleles $\left(N_{\mathrm{E}}\right)$, genetic diversity of Nei $\left(\hat{\mathrm{H}}_{\mathrm{E}}\right)$, percentage of polymorphic loci (P\%), and the Shannon index (I) (Smith, 2002).

Genetic structure of population was carried out on the Bayesian clustering model, using the STRUCTURE v.2.3.3 software (Hubisz et al., 2009). The set of parameters assumed the "admixture" model, with correlated allele frequencies. Simulations were performed in burn-in of 100,000 replications, with values of $\mathrm{k}$ ranging from 2 to 8 . The number of clusters $(\triangle \mathrm{K})$ was estimated according to the STRUCTURE HARVESTER of Evanno method (Earl and VonHoldt, 2012).

\section{RESULTS}

The seed source population $(\mathrm{P})$ presented genetic similarity ranging from 33 to $68 \%$ and the average value was $43.63 \%$. There was low genetic similarity $(41 \%)$ among the individuals of this population, even when they presented low geographical proximity ( $\mathrm{St}_{6}$ and $\left.\mathrm{St}_{14}-30 \mathrm{~m}\right)$. The most geographically distant individuals, $\mathrm{St}_{1}$ and $\mathrm{St}_{8}(1.125 \mathrm{~m})$ presented $46 \%$ of genetic similarity. The correlation matrix between the genetic diversity and spatial distance was negative and significant $(\mathrm{r}=-0.364$ and $\mathrm{P}=0.0097)$.

In the recovered area $(\mathrm{R})$, the mean genetic similarity was superior compared with population $\mathrm{P}$, with values of 55.62 and $43.64 \%$, respectively. Population $\mathrm{P}$ has fixation index $(f)$ of 0.30 . Due to the geographical distance $(10.52 \mathrm{~km})$ between the regions of the National Forest of Ibura and the region of São Cristóvão, the mixture of seed subsamples of these two areas could contribute to increasing the genetic diversity in the recovered area (R) (Figure 1).

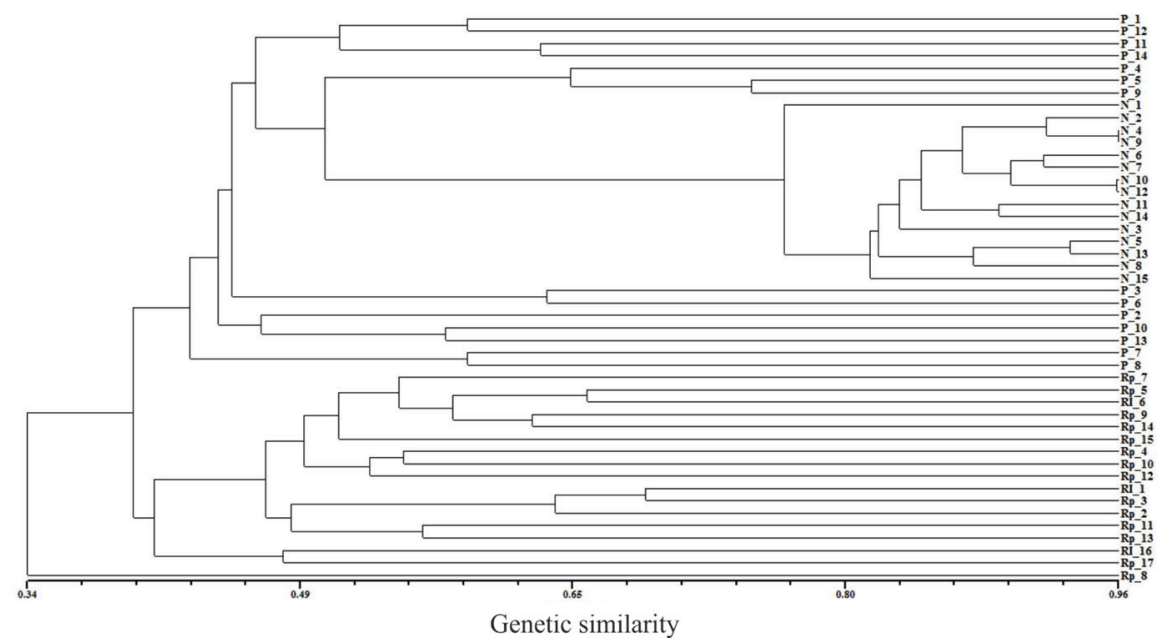

Figure 1. Genetic similarity of populations of Schinus terebinthifolius in the State of Sergipe. P: Population used for seed collection - São Cristóvão/SE; Rp: individuals originated from seeds of population P; RI: individuals originated from the National Forest Ibura, Socorro/SE; N: individuals belonging to natural population located next to the recovered area, in the municipality of Santana do São Francisco/SE.

Genetics and Molecular Research 16 (2): gmr16029669 
The native population $(\mathrm{N})$ presents high genetic similarity (70 to $95.91 \%$ ) low value of heterozygosity $(0.218)$ and the Shannon index $(0.318)$ for this population when compared with the others (Table 1).

\section{Table 1. Genetic parameters of individuals of Schinus terebinthifolius located in the State of Sergipe.}

\begin{tabular}{l|c|c|c|c}
\hline & $\mathrm{N}$ & $N_{\mathrm{E}}$ & $H_{\mathrm{E}}$ & $\mathrm{I}$ \\
\hline Population 1 (P1) & 14 & 1.579 & 0.345 & 0.519 \\
\hline Recovered area (R2) & 17 & 1.535 & 0.315 & 0.478 \\
\hline Natural population (N3) & 15 & 1.385 & 0.218 & 0.318 \\
\hline
\end{tabular}

P1: donor population used for seed collection - São Cristóvão/SE; R2: population originated from seeds of the P1 population - Santana do São Francisco/SE. N = number of individuals sampled; $N_{\mathrm{E}}=$ effective number of alleles per locus; $H_{\mathrm{E}}=$ genetic diversity; $\mathrm{I}=$ Shannon index.

For the PCoA (Figure 2) three clusters were obtained, and each sampled population was represented by a cluster, consistent with the high genetic differentiation $\left(F_{\mathrm{ST}}\right)(0.39)$.

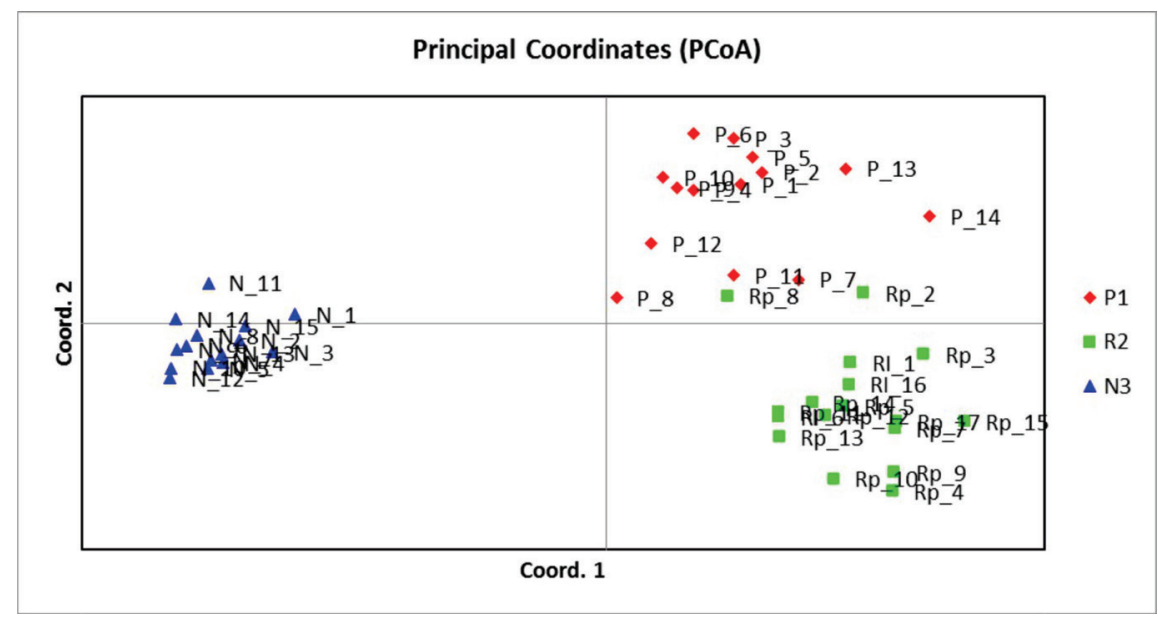

Figure 2. Principal coordinate analysis of populations of Schinus terebinthifolius located in the State of Sergipe. P1: Population used for seed collection - São Cristóvão/SE; R2: population originated from seeds of the P1 population - Santana do São Francisco/SE.

Heterozygosities $\left(H_{\mathrm{E}}\right)$ observed for populations were $0.34(\mathrm{P}), 0.31(\mathrm{R})$, and $0.21(\mathrm{~N})$ (Table 1), and the genetic structure by the Bayesian analysis presented three genetic clusters $(\Delta \mathrm{K}=3)$ (Figure 3).

\section{DISCUSSION}

Studies on S. terebinthifolius populations are important due to exploitation of pink pepper fruits for subsequent use in agroindustries, which has led local communities to extract large amounts of the fruit in the Lower São Francisco (Jesus and Gomes, 2013), despite the constant dissemination of the impacts that the irrational exploitation of individuals causes breaking branches or even trees suppression. Thus, the recovery of these areas should become a public policy for vegetation restoration.

Genetics and Molecular Research 16 (2): gmr16029669 


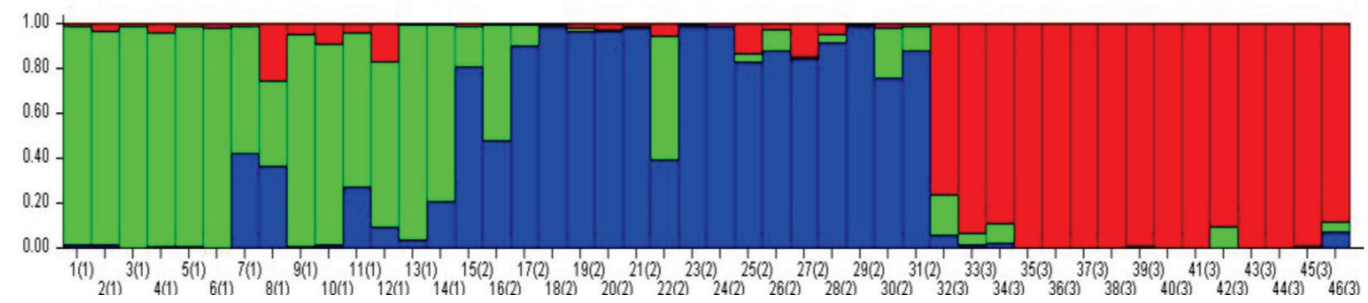

Figure 3. Genetic structure of populations of Schinus terebinthifolius: 1-14: population P (seed trees) (São Cristóvão); 15-31: population R (individuals originated from seeds of population P (São Cristóvão), and the National Park of Ibura (Socorro), located and recovered in the municipality of Santana do São Francisco); 32-46: population N (natural population located in the municipality of Santana do São Francisco), obtained by Bayesian analysis. The $\mathrm{y}$-axis indicates the rainfall percentage in each of the estimated $\mathrm{K}$ groups.

The main object for the establishment of recovery areas, seeds should be collected at a recommended minimum distance of 50 to $100 \mathrm{~m}$ (Kageyama and Gandara, 1999). However, when working in extremely fragmented areas, or with few matrices per area, the recommendation distance is unfeasible to be used as standardization. Although some seed trees of population $\mathrm{P}$ present spatial distances shortest than $50 \mathrm{~m}$, there is low genetic proximity (Gaia et al., 2004).

In a study of genetic diversity in natural populations of Enterolobium contortisiliquum, with eight individuals, in the Lower São Francisco - Sergipe, low genetic similarity (46\%) was observed, despite being located at approximately $40 \mathrm{~m}$ spatial distance. Genetic similarity between the most distant pair of individuals $(110 \mathrm{~m})$ presents the highest value $(67 \%)$, although the spatial distance between them is above the recommended distance (Santana et al., 2008). For the authors, by making proper management in seed collection for seedling production, it is possible to use these matrices as seed trees. Besides, studies on Ziziphus joazeiro Mart. in population located in the municipality of Canhoba (Sergipe), with collection carried out in the recommended minimum spacing between supplying seeds of $50 \mathrm{~m}$, the mean genetic similarity was $55.0 \%$, and similarity ranged from 32 to $68 \%$ (Gois et al., 2014), which are values similar to those found in population $\mathrm{P}$ of $\mathrm{S}$. terebinthifolius.

In the population $\mathrm{P}$, it is evident the absence of a spatial distribution pattern with the genetic distances, reinforcing that stochastic effects can prevail over environmental patterns (Hubbell, 2001). Given the results, obtaining genetic diversity is important for a low number of individuals, even if they present geographic proximity, i.e., less than $50 \mathrm{~m}$. For seed collection programs, the most relevant factor for the population sustainability is to maintain heterozygosity.

Heterozygosity or genetic diversity of Nei $\left(H_{\mathrm{E}}\right)$ in the population $(\mathrm{P}=0.34, \mathrm{R}=$ 0.31 and $\mathrm{N}=0.21$ ) is of the standard, which is usually found for tree species. Populations of Trichilia pallida Swartz located in the Santa Geneva Reserve (Campinas) in the Ecological Station of Caetetus, in Gália (São Paulo), presented mean $H_{\mathrm{E}}$ of 0.33 (Zimback et al., 2004). Schizolobium parahyba populations found in conservation units, forest edges, pastures, banana crops, and in populations inserted in an urban area (Paraty) presented $H_{\mathrm{E}}$ of 0.36 (Freire et al., 2007). Studies on native populations of Ziziphus joazeiro Mart., located in different municipalities of the Lower São Francisco - Sergipe, observed $H_{\mathrm{E}}$ of 0.25 (Santana do São Francisco/15 individuals), 0.30 (Canhoba/19 individuals), and 0.24 (Canindé de São Francisco/20 individuals) (Gois et al., 2014). 
Although the values of genetic diversity may be different, since they depend on intrinsic factors, such as the crossing system and the effective population size, as well as extrinsic factors, such as the number of sampled individuals, fragmentation, and isolation of the sampled areas, among others (Kramer et al., 2008), higher $H_{\mathrm{E}}$ values in both populations ( $\mathrm{P}$ and $\mathrm{R}$ ) present moderate heterozygosity levels. However, population $\mathrm{N}$ deserves special attention due to its low heterozygosity.

Despite the decrease of heterozygosity in population $\mathrm{R}$, probably due to inbred crosses $(f=0.30)$ in population $P$, heterozygosity is still above values found for some native populations using a sample and different types of markers.

A study carried out with $S$. terebinthifolius in native populations located next to the recovered area described that the native population presents $H_{\mathrm{E}}$ of 0.20 (Carvalho et al, 2013). Also, more recent studies comparing native fragments in three different regions of the State of Sergipe (Caatinga/30 individuals; Ecotone/47 individuals; Atlantic Forest/85 individuals) also presented lower genetic diversity $\left(H_{\mathrm{E}}=0.20\right)$ in each studied region (Álvares-Carvalho et al., 2015). Another study using simple sequence repeats and 30 sampled individuals revealed $H_{\mathrm{E}}$ of 0.28 (ÁlvaresCarvalho et al., 2016), lower heterozygosity than that of the recovered area $(\mathrm{R}=0.31)$.

Although the first seed collection strategy in two distant regions (population $\mathrm{P}$ and Ibura) failure to ensure the increment of genetic diversity when compared with populations $P$ and $\mathrm{R}$, when associated with other parameters. Moderate genetic differentiation was observed between population $\mathrm{P}$ and population $\mathrm{R}\left(F_{\mathrm{ST}}=0.23\right)$, the mean values usually found for tree species, since several studies indicate that $F_{\mathrm{ST}}$ values between 0.22 and $0.36(005>\mathrm{P}>0.01)$ are usually reported for cross-breeding system species or primary successional stage (Nybom, 2004). Thus, the value of genetic differentiation between populations clearly distinguishes individuals of populations $\mathrm{P}$ and $\mathrm{R}$, evidencing that although the percentage of the genetic similarity between populations of São Cristóvão and Ibura, the introgression of individuals in two areas could ensure the success of the recovery area; this is evidenced especially by comparing the genetic diversity of Nei of population $\mathrm{R}\left(H_{\mathrm{E}}=0.31\right)$ with that of population $\mathrm{N}\left(H_{\mathrm{E}}=0.21\right)$. The low genetic diversity of Nei in population $\mathrm{N}$ confirms the need for action aimed at immediate genetic enrichment for the maintenance of the genetic diversity of the species over time in the recovered area on the banks of the São Francisco River.

By the PCoA, a greater genetic distance was observed among individuals from population $\mathrm{N}$ and the others, which are formed by populations $\mathrm{P}$ and $\mathrm{R}$. However, both populations ( $\mathrm{P}$ and $\mathrm{R}$ ) have subdivision trend (Figure 2), which is consistent with the moderate levels of genetic similarity among individuals.

The Bayesian analysis inferred the formation of three clusters $(\Delta \mathrm{K}=3)$, and each cluster was represented by a population. The low genetic structure of the three populations analyzed confirms the high levels of genetic differentiation found between populations $\left(F_{\mathrm{ST}}\right.$ $=0.39$ ). Probably this low structuring of population $\mathrm{R}$ is due to inbred crosses $(f=0.30)$ present in $\mathrm{P}$, resulted in seeds with a genetic background very similar to the seedlings from the National Forest of Ibura, and make up the recovered population (R). This fact consequently led to moderate genetic differentiation between populations $\mathrm{P}$ and $\mathrm{R}\left(F_{\mathrm{ST}}=0.23\right)$, and to the low genetic structure in the recovered population. Although individuals of the population $\mathrm{R}$ present unstructured population by the Bayesian analysis, this population shows significant levels of $H_{\mathrm{E}}$ (Table 1). However, the sustainability of this population is only ensured with the genetic exchange between individuals belonging to the native population of the surroundings, due to the presence of different genetic sets.

Genetics and Molecular Research 16 (2): gmr16029669 
By comparing the recovered area $(\mathrm{R})$ with the natural population located in the surroundings $(\mathrm{N})$ using the Bayesian analysis (Figure 3), each population showed predominance of a genetic cluster, which leads to the inference that crosses between the two populations would favor the increase of diversity to subsequent generations, and this will promote the structuring of the population in relation to the clusters analyzed. The gene flow between populations can ensure the sustainability and maintenance of populations if management practices are used to ensure the in situ establishment of subsequent generations.

\title{
ACKNOWLEDGMENTS
}

\author{
The authors thank CAPES and CNPq for their financial support.
}

\section{REFERENCES}

Álvares-Carvalho SV, Duarte JF, Carvalho D, Pereira GS, et al. (2015). Schinus terebinthifolius: Population structure and implications for its conservation. Biochem. Syst. Ecol. 58: 120-125. https://doi.org/10.1016/j.bse.2014.10.002

Álvares-Carvalho SV, Duarte JF, Santos TC, Santos RM, et al. (2016). Structure and genetic diversity of natural Brazilian pepper populations (Schinus terebinthifolius Raddi). Genet. Mol. Res. 15: 1-13. https://doi.org/10.4238/gmr.15028123

Brasil (2006). Ministério do Meio Ambiente. Ministério do Meio Ambiente, Mata Atlântica, Brasília. Available at [http:// www.mma.gov.br/biomas/ mata-atlantica/mapa-da-area-de-aplicacao].

Carvalho SVA, Mann RS, Ferreira RA, Melo MF de V, et al. (2013). Diversidade genética. In: Pensando a biodiversidade: aroeira (Schinus terebinthifolius Raddi) (Gomes LJ, Silva-Mann R, Mattos PP and Rabbani ALC, eds.). Universidade Federal de Sergipe, São Cristóvão, 89-108.

Earl DA and VonHoldt BM (2012). STRUCTURE HARVESTER: a website andprogram for visualizing STRUCTURE output and implementing the Evanno method. Conserv. Genet. Resour. 4: 359-361 https://doi.org/10.1007/s12686$\underline{011-9548-7 .}$

Frankham R, Ballou JD and Briscoe DA (2010). Introduction to Conservation Genetics. 2nd edn. Cambridge University Press, Cambridge.

Frankham R, Bradshaw CJA and Brook BW (2014). Genetics in conservation management: Revised recommendations for the 50/500 rules, Red List criteria and population viability analyses. Biol. Conserv. 170: 56-63. https://doi. org/10.1016/j.biocon.2013.12.036

Freire JM, Piña-Rodrigues FCM, Lima ER, Sodré SRC, et al. (2007). Estrutura genética de populações de Schizolobium parahyba (Vell.) Blake (guapuruvu) por meio de marcadores RAPD. Sci. For. 74: 27-35.

Gaia JMD, Mota MG da C, Conceição CCC da, Costa MR, et al. (2004). Similaridade genética de populações naturais de pimenta-de-macaco por análise RAPD. Hortic. Bras. 22: 4. https://doi.org/10.1590/S0102-05362004000400004

Gois IB, Ferreira RA, Pantaleão SM, Gois CB, et al. (2014). Variabilidade genética em populações naturais de Ziziphus joazeiro Mart por meio de marcadores moleculares RAPD. Rev. Arvore 38: 621-630. https://doi.org/10.1590/S0100$\underline{67622014000400005}$

Hubbell SP (2001). The Unified Neutral Theory of Biodiversity and Biogeography. Monographs on Population Biology. Princeton University Press, New Jersey.

Hubisz MJ, Falush D, Stephens M and Pritchard JK (2009). Inferring weak population structure with the assistance of sample group information. Mol. Ecol. Resour. 9: 1322-1332 https://doi.org/10.1111/j.1755-0998.2009.02591.x.

Jesus NC and Gomes LJ (2013). Importância socioeconômica. In: Pensando a biodiversidade: aroeira (Schinus terebinthifolius Raddi) (Gomes LJ, Silva-Mann R, Mattos PP and Rabbani ALC, eds.). Universidade Federal de Sergipe, São Cristóvão, 56-83.

Kageyama PY, Gandara FB (1999). Restauração, conservação genética e produção de sementes. In: Simpósio Mata Ciliar: Ciência e Tecnologia, Belo Horizonte, MG Anais. UFLA, Lavras, 59-68.

Kramer AT, Ison JL, Ashley MV and Howe HF (2008). The paradox of forest fragmentation genetics. Conserv. Biol. 22: 878-885. https://doi.org/10.1111/j.1523-1739.2008.00944.x

Lino CF (2013). Panorama do cumprimento das metas de AICHI-CDB 2020 na Mata Atlântica: avanços, oportunidades e desafios. Anuário Mata Atlântica, São Paulo, 1-90. Available at [http://www.rbma.org.br/ anuariomataatlantica/pdf/ panorama_portugues.pdf]. Accessed February 1, 2014.

Genetics and Molecular Research 16 (2): gmr16029669 
Nienhuis J, Tivang J, Skroch P and Dos Santos JB (1995). Genetic relationships among cultivars and landraces of lima bean (Phaseolus lunatus L) as measured by RAPD markers. J. Am. Soc. Hortic. Sci. 120: 300-306.

Nybom H (2004). Comparison of different nuclear DNA markers for estimating intraspecific genetic diversity in plants. Mol. Ecol. 13: 1143-1155. https://doi.org/10.1111/j.1365-294X.2004.02141.x

Peakall ROD and Smouse PE (2006). Genalex 6: genetic analysis in Excel. Population genetic software for teaching and research. Mol. Ecol. Notes 6: 288-295. https://doi.org/10.1111/j.1471-8286.2005.01155.x

RBMA (2008). Reserva da Biosfera da Mata Atlântica. Revisão da Reserva da Biosfera da Mata Atlântica. Avaliable at [http://www.rbma.org.br/rbma/rbma_fase_vi_06_estados_se.asp]. Accessed May 10, 2017.

Rohlf FJ (2001). Numerical taxonomy and multivariate analysis system. New York. Version 2.1.

Santana GC, Mann RS, Ferreira RA, Góis IB, et al. (2008). Diversidade genética de Enterolobium contortisiliquum (Vell) Morong, no Baixo São Francisco, por meio de marcadores RAPD. Rev. Arvore 32: 427-433. https://doi.org/10.1590/ $\underline{\text { S0100-67622008000300005 }}$

Sebbenn AM, Kageyama PY and Vencovsky R (2003). Conservação genética in situ e número de matrizes para a coleta de sementes em população de Genipa americana L. Sci. For. 63: 13-22.

Smith LI (2002). A tutorial on Principal Components Analysis. University of Otago, New Zealand. Available at [http:// www.cs.otago.ac.nz/cosc453/student tutorials/principal_components.pdf]. Accessed January 20, 2017.

Wang J (2005). Estimation of effective population sizes from data on genetic markers. Philos. Trans. R. Soc. Lond. B Biol. Sci. 360: 1395-1409 https://doi.org/10.1098/rstb.2005.1682.

Williams JGK, Kubelik AR, Livak KJ, Rafalski JA, et al. (1990). DNA polymorphisms amplified by arbitrary primers are useful as genetic markers. Nucleic Acids Res. 18: 6531-6535. https://doi.org/10.1093/nar/18.22.6531

Zimback L, Mori ES, Kageyama PY, Veiga RFA, et al. (2004). Estrutura genética de populações de Trichilia pallida Swartz (Meliaceae) por marcadores RAPD. Sci. For. 65: 114-119.

Genetics and Molecular Research 16 (2): gmr16029669 